Sains Malaysiana 50(4)(2021): 1187-1198

http://doi.org/10.17576/jsm-2021-5004-28

\title{
Positive and Negative Effects of COVID-19 Pandemic on Aquatic Environment: A Review
}

(Kesan Positif dan Negatif Pandemik COVID-19 ke atas Persekitaran Akuatik: Suatu Ulasan)

\author{
Ong Meng Chuan*, Adiana Ghazali, Roswati Md Amin, Kesaven Bhubalan, Lee Jen Nie, Tuan \\ Mohamad Fauzan Tuan Omar, IdHam Khalil, Suvik Assaw, Yong Jaw Chuen, Nurulnadia Mohd \\ YuSOFF, IZAN JAAFAR, WAN NURUL NADIAH WAN RASDI, NURZAFIRAH MAZLAN, MifTAHUL JANNAH \\ Muhammad Husin, Radin Maya Saphira Radin Mohamed, Zurahanim Fasha Anual, Chen Mengli \& \\ MARFIAH AB WAHID
}

\begin{abstract}
In December 2019, a novel coronavirus called severe acute respiratory syndrome coronavirus 2 (SARS-CoV-2) outbreak was reported for the first time in Wuhan, Hubei province, China. This coronavirus has been referred as Coronavirus Disease 2019 or COVID-19 by World Health Organization (WHO). The spread of COVID-19 has become unstoppable, infecting around 93.5 million people worldwide, with the infections and deaths still increasing. Today, the entire planet has changed due to the greatest threat on the planet since the introduction of this lethal disease. This pandemic has left the world in turmoil and various measures have been taken by many countries including movement control order or lockdown, to slow down or mitigate the infection. Since the lockdown has been implemented almost in all affected countries, there has been a significant reduction in anthropogenic activity, including a reduction in industrial operations, vehicle numbers, and marine-related activities. All of these changes have also led to some unexpected environmental consequences. As a result of this lockdown, it had a positive and negative impact on the environment including the aquatic environment. Hence this review will therefore focus on the good and bad perspectives of the lockdown toward the aquatic environment.
\end{abstract}

ABSTRACT

Keywords: Anthropogenic; aquatic environment; COVID-19; lockdown; pollution

\section{ABSTRAK}

Pada Disember 2019, satu koronavirus baru yang dikenali sebagai SARS-CoV-2 telah merebak dan dilaporkan untuk pertama kalinya di Wuhan, Wilayah Hubei, China. Koronavirus ini telah dinamakan sebagai Coronavirus Disease 2019 atau pandemik COVID-19 oleh Pertubuhan Kesihatan Dunia (WHO). Penyebaran COVID-19 ini tidak dapat dikawal dan dihentikan dan telah menjangkiti hampir 94.5 juta manusia di seluruh dunia dengan kadar jangkitan dan kematian masih meningkat pada hari ini. Kini, persekitaran bumi telah berubah kerana ancaman terbesar sejak kemunculan wabak ini. Pandemik ini juga menjadikan seluruh dunia menjadi panik dan pelbagai langkah telah diambil oleh kebanyakan negara termasuk perintah kawalan pergerakan untuk memperlahankan dan mengawal jangkitan ini. Sejak perintah ini dilaksanakan di kesemua negara yang terjejas di seluruh dunia, aktiviti antropogen telah berkurangan secara signifikan, termasuk aktiviti perindustrian, jumlah kenderaan di jalan raya dan juga aktiviti berkaitan dengan laut. Semua perubahan ini turut membawa kepada perubahan persekitaran yang tidak dijangka oleh manusia. Hasil daripada kawalan ini, ia memberi kesan positif dan juga negatif terhadap alam sekitar termasuklah persekitaran akuatik. Oleh itu, ulasan ini akan menumpukan kepada perspektif baik dan buruk perintah kawalan pergerakan terhadap persekitaran akuatik.

Kata kunci: Antropogen; COVID-19; kawalan pergerakan; pencemaran; persekitaran akuatik

\section{INTRODUCTION}

The coronavirus disease 2019 or well known as COVID-19 (Lai et al. 2020) is becoming a hot issue and a big world crisis. The first case of this virus was detected in Wuhan City, Hubei Province, Central China. It was reported to the WHO Country Office in China on $31^{\text {st }}$ December 
2019 before it spreads and shocks people worldwide ( $\mathrm{Lu}$ et al. 2020). To date, more than 94.5 million cases with a total of 2.1 million deaths reported in 200 countries and territories around the world, with the United States, India, Brazil, and Russia currently experiencing the most widespread have been affected by this deadly virus. The COVID-19 can spread via airborne zoonotic droplets, in which the animals spread the virus to humans (Ahmad et al. 2020; Chakraborty et al. 2020). However, this virus has undergone some genetic mutations that enable it to afflict humans and can be transmitted among humans itself (Shereen et al. 2020). When this transmission occurred, the confirmed cases increased (Adhikari et al. 2020) and still growing today.

The outbreaks of COVID-19 are far more than a health emergency (Sohrabi et al. 2020; Wenham et al. 2020). This pandemic has affected every segment of the human population such as economic (Nicola et al. 2020) and social (Van Lancker \& Parolin 2020) crisis and as well as environmental quality (Abdullah et al. 2020; Wang $\& \mathrm{Su} 2020$ ). The emergence of COVID-19 has become unstoppable since an outbreak in late December. It has been increasing day by day to date. Because of the global threat, on $30^{\text {th }}$ January 2020, the World Health Organization (WHO) declared COVID-19 a Public Health Emergency of International Concern (PHEIC). WHO (2020) announced on $11^{\text {th }}$ March 2020 that COVID-19 had been adjudicated as a pandemic that propagates across dozens of countries or continents. This pandemic declaration was due to the sudden increase in the number of positive cases reported with this virus outside the country of origin, China over the past two weeks worldwide.

Since the number of cases related to COVID-19 is expected to increase further, WHO Regional Director for Europe, Dr. Hans Henri P. Kluge advises countries worldwide to continue implementing a containment strategy while speeding up their efforts to control the disease (WHO 2020). Despite this, most country leaders have announced a national lockdown to fight the spread of COVID-19 (Hamzelou 2020). In Malaysia, the government has announced several levels of lockdown namely, Movement Control Order (MCO), Conditional Movement Control Order (CMCO), Recovery Movement Control Order (RMC) that started from $18^{\text {th }}$ March 2020 to date. This order stops all non-essential businesses and activities or may operate at minimum conditions while implementing government rules and regulations. People are encouraged to limit their outdoor activities and work from home. After a few weeks of implementation, this approach showed positive feedback when the number of confirmed new cases of COVID-19 began to decline (Deshwal 2020; Lau et al. 2020).

Since the lockdown has taken place around the world, most of the positive impacts on the aquatic environment can be seen from the naked eye (Chen et al. 2020; Saadat et al. 2020). However, we are concerned about the negative impact or invisible pollutants such as chemical and biological pollutants that enter the aquatic. Most of these pollutants may build up in the environment through bioaccumulation, biomagnification and bioconcentration processes from unnoticed to toxic levels (Álvarez-Ruiz \& Picó 2020; Loften et al. 2018; Ong \& Gan 2017). In this review, we summarise the positive and negative impacts of COVID-19 pandemic lockdown on the environment, particularly in the aquatic environment.

\section{LOOKING AT THE POSITIVE PERSPECTIVES}

Reduced emission of carbon dioxide $\left(\mathrm{CO}_{2}\right)$ gas and ocean acidification

Since the lockdown enforcement implements worldwide, offices, businesses, and industrial activities have been shut down. Transport networks are also dwindling due to the shutdown of domestic and international routes. The running of trains, busses and vessels have also been ceased to operate. As quickly as all these activities stopped, the major problems we have been fighting for decades have happened in a few days and nature has become accustomed to it. All of these have significantly reduced fossil fuel consumption (Dutheil et al. 2020) and as a result, $\mathrm{CO}_{2}$ emission has been touched the trough in the existing $\mathrm{CO}_{2}$ profile of the region. It has led to a sudden drop (Figure 1) as much as $40 \%$ in $\mathrm{CO}_{2}$ emission profile in the atmosphere of the major cities around the world (Fattorini \& Regoli 2020; Zhu et al. 2020a) such as Kolkata, India (Mitra et al. 2020), Barcelona, Spain (Tobías et al. 2020), São Paulo, Brazil (Freitas et al. 2020) and Kuala Lumpur, Malaysia (Suhaimi et al. 2020).

Several scientists have proved that $\mathrm{CO}_{2}$ is more than greenhouse gases that are the leading gases responsible for ocean acidification (Kitidis et al. 2017). Atmosphere exchanges with the sea and interactions with atmospheric $\mathrm{CO}_{2}$ usually lead to this phenomenon (Williamson et al. 2017). The excess anthropogenic atmospheric $\mathrm{CO}_{2}$ is absorbed by the ocean, becomes aqueous and reacts with $\mathrm{H}_{2} \mathrm{O}$ to form carbonic acid $\left(\mathrm{H}_{2} \mathrm{CO}_{3}\right)$ (Doney et al. 2009). This carbonic acid can dissociate itself by losing hydrogen ions to create carbonate $\mathrm{CO}_{3}{ }^{2-}$ and bicarbonate $\mathrm{HCO}_{3}^{-}$ions. Study by Raven (2005) shows that a 0.1 reduction in $\mathrm{pH}$ can increase $30 \%$ of hydrogen 

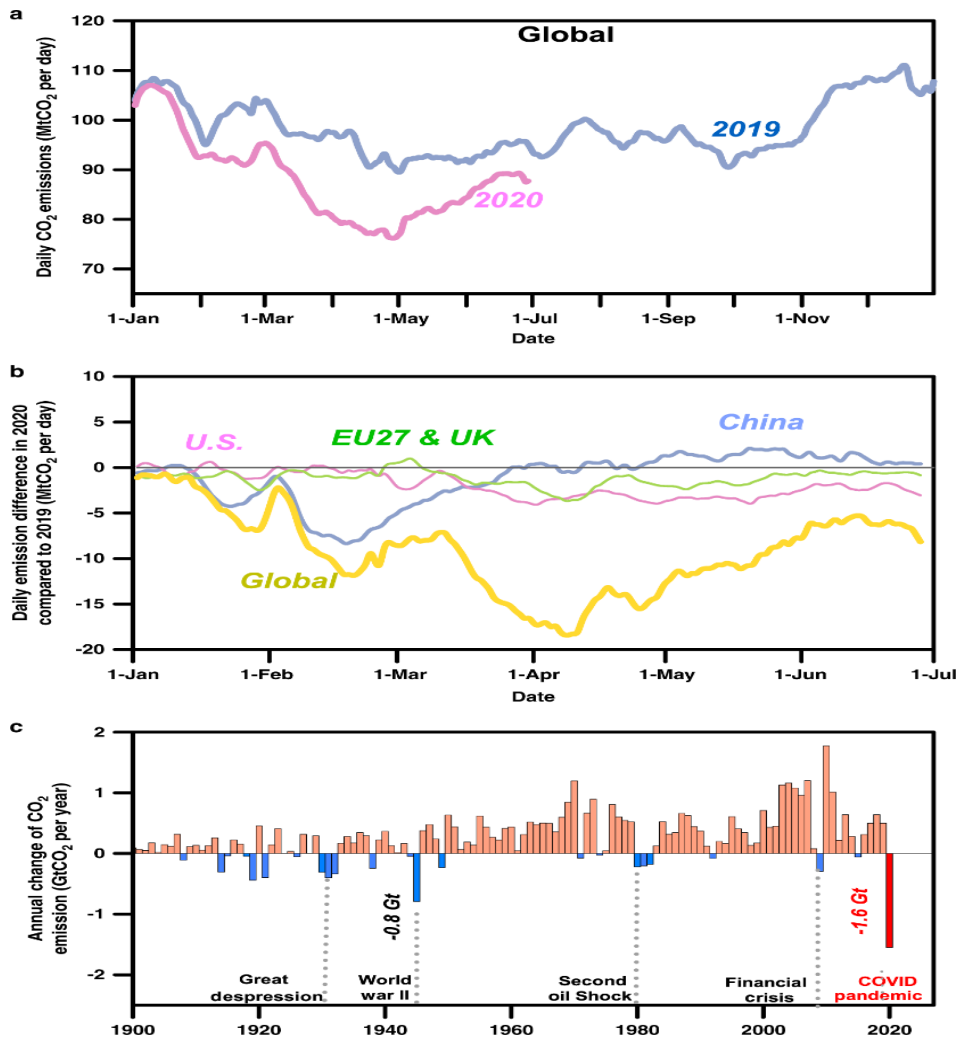

FIGURE 1. Effect of pandemic COVID-19 lockdown on global $\mathrm{CO}_{2}$ emissions (Zhu et al. 2020b)

ion concentration in the ocean. The liberation of hydrogen ions in the seawater leads to decreased $\mathrm{pH}$ and can affected marine organisms (Doney et al. 2009).

The lower concentration of $\mathrm{CO}_{2}$ in oceans for a few months during the lockdown is still beneficial for coral reefs and all calcifying organisms (Connel et al. 2017) such as oysters and clams. Gagliano et al. (2010) reported the mean $\mathrm{pH}$ for the world's open oceans ranges from 7.9 to 8.3 , and this range is suitable for almost all marine organisms. If the sources of ocean acidification dropped drastically during the last months, we could expect to see changes in ocean $\mathrm{pH}$ worldwide. With no continuous input of $\mathrm{CO}_{2}$ into the atmosphere, oceans could have absorbed enough carbon dioxide (DeVries et al. 2017) to return to the once usual equilibrium of $\mathrm{CO}_{2}$ concentrations in the atmosphere. With normal interactions between air and water, we can expect to see an increase in $\mathrm{pH}$, thus ocean basification can occur (Brodersen et al. 2020).
Improve the clarity and quality of water

Anthropogenic by human activities can mechanically disturb water chemistry (Batista et al. 2016; Fernandes et al. 2020). Plus, boat propellers mix the different layers and add oxygen in the first one, thus modifying the water chemistry (Sagerman et al. 2020). Indeed, maritime traffic, recreational, and fishing boats create waves when their propellers mix the water (Burgin \& Hardiman 2011). This water turbulence can stir up sediment, resulting in shading of aquatic plants due to increased water turbidity and in smothering when sediment settles on the shoots (Sagerman et al. 2020). Since a single boat does not have a tremendous impact, the number used daily across the world is substantial. Most of the aquatic environments used to be brownish before the lockdown but are now blue and crystal clear (Lokhandwala \& Gautam 2020).

For example, In Italy, with a nationwide lockdown established on the $9^{\text {th }}$ March 2020 (Zanin et al. 2020), 
the canals of Venice have seen an improvement in water clarity due to the reduction of water traffic, not only from the tourist-famous gondolas but notably from motorised boats including Vaporetto water buses, main transportation for the Venetian and cruise ships (Braga et al. 2020). In effect, the greater water flow and visibility is not a result of lower pollution but rather a reduction of sediment stirring (Bilkovic et al. 2019). The improved water clarity has led to reports of previously obscured many aquatic species that were not present before the pandemic such as the reappearance of small fish, crabs, jellyfish and seaweeds within the canals (Brunton 2020).

Since the lockdown in Malaysia, reduced commercial activities have been reported to reduce waste produced and sullage water which ends up in rivers without wastewater treatment. As a result, many communities in the Klang Valley, particularly in Sungai Kemusing, Sungai Way and Sungai Gombak have reported improved water clarity in many rivers (Goi 2020). One significant example is Sungai Melaka, which before the MCO, the river water was murky and brown colour (The Star 2020). Most evidence of improved water quality remains anecdotal; a survey from the Department of Environment (DOE) of Malaysia, ammoniacal nitrogen, biochemical oxygen demand, dissolved oxygen, $\mathrm{pH}$ and total suspended solid data from 29 water monitoring stations in Malaysia indicated an improved river water quality index (Goi 2020).

\section{Reduced acoustic pollution of the marine environment}

The introduction of noise into the marine environment may significantly impact marine species and ecosystems (Peng et al. 2015). Many marine animals use sound and acoustics energy to adapt to their environment (Stocker 2002). The COVID-19 pandemic was also linked to a reduction in marine acoustic pollution (Thomson \& Barclay 2020) as well as terrestrial pollution. For example, in British Columbia, Canada, there has been a significant decrease in cruise ships and freight shipping, with imports and exports falling by $16 \%$ in some ports compared to 2019, according to Statistic Canada (Bennett et al. 2020). Researchers analysing real-time sound signals from Ocean Networks Canada underwater observatories reported a significant drop in low-frequency sounds off Vancouver Island and the coast of British Columbia since the onset of the pandemic (Thomson \& Barclay 2020). Several studies reported that the acoustic pollution can cause changes in individual and social behaviour, auditory masking, population distribution and abundance and other physiological impacts of the marine organisms (Peng et al. 2015; Rako-Gospić \& Picculin 2019). Considering the detrimental effects of acoustic pollution on marine mammals, notably cetaceans such as baleen whales (Mysticeti) and toothed whales (Odontoceti), which rely on high to low frequency sounds for navigation, communication and/or hunting, the biological implications of quieter oceans could be substantial (Jiang et al. 2021).

The recovery of aquatic life and fishery resources Due to the effects of the COVID-19 lockdown measures, notably with restaurants and hotels' closure, reduced demand for fish and seafood has affected many parts of the world (Korten 2020). Furthermore, as many fishing vessels around the world are unable to leave harbour due to movement control orders and an increased risk of transmission to crews, fish populations may see a respite from fishing to allow the recovery of populations (Korten 2020). Korten (2020) estimates that if fishing activities are limited for more than a year, long-enough to allow for a large number of species to complete their spawning cycles, these species could proliferate, allowing the fish recovery stocks above current levels. In Europe, after a year's fishing break, it has been suggested that stocks of herring, flatfish and whitefish could double in biomass.

Since this lockdown began mostly in March, it can help marine life to recover and conservation plans to achieve their goals more quickly, as many species breed between March and May in the Mediterranean (Aspillaga et al. 2016) and between April and June in the Atlantic (Mazzoni et al. 2018). For example, sea turtles have benefited from the reduction of tourism and their offspring could reach the sea without any disturbance because the beaches are cleaner and with less noise and people. In addition, the peak nesting season for sea turtles was estimated to occur between May and June (Salleh et al. 2018).

\section{RECOVERY OF CORAL REEFS COMMUNITIES}

Coral reefs are often pressured by natural disasters and anthropogenic influence. Over the years, the decline of coral reefs health is more often related to climate change, major coral bleaching events, and physical disturbances such as urbanization, trawling and fish bombing (Lough et al. 2018). The nature and usage of coral reefs provide food for the local people, a shelter for marine organisms, recreational and tourism activities, and coastal protection (Praveena et al. 2012). If the coral reefs are wisely managed over the years of human evolution, the coral reefs still can maintain the optimal function by providing essential services. But as human population increases and lack of awareness, the damage of coral reefs are now cannot be revert. The cause of coral reef degradation can be due to high sedimentation loads (Lee \& Mohamed 
2011), increases of human settlement which related to deforestation and agriculture, river runoff (Edinger et al. 1998) and fish bombing (Alcaca \& Gomez 1979). Recovery of coral reefs can be short as in 10 years or more than 40 years (Steneck et al. 2019), according to the level of damage and recovery processes.

During the COVID-19 outbreak in Malaysia, the east coast of Peninsular Malaysia just ended the monsoonal cycle from mid-November to mid-February (3 months). Movement Control Order (MCO) was enforced in midMarch 2020 which require all business to stop operating except essential services. Stringent lockdowns with no traveling between countries or states certainly reduced the tourism impacts on coral reefs. This generally gives a positive input to the coral reefs within the area. Several studies also reported the enhancement of the marine ecosystem and improved the health of the environment (Edwards et al. 2021; Gordon 2020; King et al. 2021). Less anthropogenic impacts such as limited boating activities that cause water pollution; wave energy from boats and ferries services that cause coastal and beach erosion; snorkelling and diving activities that increase sedimentation, sunblock pollution, noise pollution; and light pollution at coastal resorts that hinder the landing of turtles nesting. Although it is not feasible to repair coral reefs to their past wellbeing (Hughes et al. 2017), active restoration and less anthropogenic influence can still provide better function and ecosystem services (Seraphim et al. 2020).

\section{LOOKING AT THE NEGATIVE PERSPECTIVES}

\section{Trash in marine environment}

Even though, reduction of anthropogenic activity due to the COVID-19 pandemic has positive impacts on the human health and marine environment, it also has created a new form of pollution to the environment. COVID-19 is caused by the coronavirus and can cause respiratory virus infection through contact (direct and indirect), droplet spray in short range transmission and aerosol in long-range transmission (airborne transmission). To control and avoid the spread of this contagious virus, WHO has advised the health workers, front liners and public to wear personal protective equipment such as wearing face mask and gloves particularly on the infected area (WHO 2020). This has caused the demand on the face mask and gloves increased rapidly worldwide and some places were in shortage.

Moreover, there are lack of information and guidance to the public on how to properly dispose the used face mask and gloves. This problem also worsen by inadequate disposal facilities to deal with the biohazard materials. Recently, in the mass media there are reports showing a glut of discarded single-use masks and gloves was washing up on shorelines and littering the seabed (The Guardian 2020 \& World Economic Forum 2020). Adding to the problem, the report also estimated that if every person used a single-use face mask a day for a year, it would create an additional 66,000 tonnes of contaminated waste and 57 , 000 tonnes of plastic packaging which greatly impacting the marine environment and human health as a new form of marine pollutant and source of water borne-diseases.

Pharmaceuticals waste in the aquatic environment

The use of pharmaceuticals and drugs to combat the COVID-19 pandemic is unavoidable. Pharmaceuticals compounds from different classes such as chloroquine, hydroxy chloroquine, azithromycin, remdesivir, lopinavir, ribavirin, and ritonavir have been widely used to treat the patient with coronavirus infection (Baron et al. 2020; Fanin et al. 2020). With the increasing number of positive cases reported worldwide, more pharmaceuticals will be introduced and tested in the future to treat this disease. Therefore, there is a concern about the elevated level of pharmaceutical residues that might infuse into the aquatic environment due to the increasing number of pharmaceuticals and drugs used in medical facilities. Previous studies have shown that pharmaceutical residues were reported in the surface water, as reported by Omar et al. (2019a) and Praveena et al. (2018). Several sources have been linked with the contamination of these residues in the aquatic environment and one of it is from hospital waste (Sim et al. 2013). The presence of pharmaceutical residues in the aquatic environment will also affect other aquatic compartments such as sediment and biota (Omar et al. 2019b, 2018). In example, Oestrogen is one of the main female sex hormones that have been found to cause hermaphroditism (Jobling et al. 2006). As we all know, the aquatic environment consisted of many organisms being used as a food source. Thus, the uptake and bioconcentration of pharmaceutical residues by aquatic organisms are of concern due to its effect on human health. Besides the aquatic environment, there is also a possibility of coronavirus transmitted through faecal sterols and subsequently contaminated the wastewater system. This has been summarized by Quilliam et al. (2020), discussing the environmental implication of shedding the SARS-CoV-2 in human faeces. The ability of coronavirus leached into wastewater might also be an important consideration because it could also occur to the pharmaceutical compounds. Although there has been report on the occurrences of pharmaceutical residues in the wastewater effluent, but with the increasing volume of drugs used to treat the disease will lead to the elevated level of pharmaceutical residues in this effluent. Therefore, the pharmaceutical residues should also be assessed in 
the wastewater treatment system especially from hospital or medical facilities that are being used for COVID-19 treatment.

During this pandemic, the world has been under lockdown for a certain period. People stay at home, which will eventually lead to high pollution load into the aquatic environment due to domestic discharge and sewage effluents. Domestic discharge and sewage effluents have been several pollution sources of pharmaceutical residues. Although various treatments methods are used to remove pharmaceutical residue from both sources, the elimination is still not satisfactory, leading to the leach of these compounds into the aquatic environment.

\section{Plastic pollution in the aquatic environment}

The increase of single-use plastics during the COVID-19 pandemic is inevitable. Frontliners use plastics as their protective gear and people have been taking takeaway food using plastic containers. Many grocery stores and restaurants have also prohibited their customers from bringing their containers or shopping bags to avoid crosscontamination. With the uncertainties in this pandemic's duration, we predict this plastic pollution will be a major issue and impact for a long-term in the future. This prediction also agreed by Praveena and Aris (2021) that a massive of plastic waste was generated in several capital city in South East Asia countries such as Kuala Lumpur, Bangkok and Singapore. Improper deposition of plastic will eventually affect the aquatic environment.

Plastics will break down into smaller pieces called microplastics and due to their tiny scale, microplastics may be eaten by several marine species who perceive them as a food supply and may thus have harmful effects (Courtene-Jones et al. 2017). There are different pathways in which plastics are released into the ecosystem and a large amount of plastic waste comprises the marine environment. Microplastics occur on the surface waters of seas, seabed sediments and in a broad range of aquatic species, such as sea birds, fish, bivalves, mammals, and crustaceans. Microplastics and their low density lead to the widespread transportation and dissemination by currents over greater distances.

These tiny marine plastics are widespread in all aquatic environments worldwide (Eerkes-Medrano et al. 2015). Although some plastics enter oceans through marine activities, $80 \%$ are believed to come from sources based on land. Discarded plastic products reach the aquatic system by freshwater waters, sewer outflows, and wind or tide transport as waste, factory runoff, or litter. Waste production and waste leakage are inextricably tied to economic growth, local infrastructure, and regulation.
It has been reported that out of 269 million tons of 5.25 trillion pollutants globally, $92 \%$ are microplastics and a hundred times smaller than predicted on the surface of the water, supporting the understanding that most microplastics sink into aquatic sediments (Eriksen et al. 2014).

Microplastics often adversely affect the essential component of the aquatic ecosystem, planktons. The presence of microplastics into the phytoplankton cell wall results in decreased absorption of chlorophyll. The heterotrophic plankton often undergoes the phagocytosis process when exposed to microplastics and preserves some tiny plastic particles in its tissues (Akdogan \& Guven 2019). Microplastics in the intestine of fish results in malnutrition and food starvation, which eventually contributes to death. Larger-microplastic beads $(5 \mathrm{~mm})$ have been reported to stay longer in the gut of the fish compared to smaller beads $(2 \mathrm{~mm})$. These findings contribute to larger microplastic particles becoming more toxic to the aquatic fish population as compared to tiny pieces because tiny microplastics may be excreted by human faeces. In addition to fish, ingestion of various forms of microplastics was observed in Norway lobster where $83 \%$ of lobsters were reported to be microfibre infected (Andrady 2017).

\section{Greywater runoff into the aquatic environment}

The amounts of greywater runoff from kitchen and laundry activities in residential buildings are expected to increase during the lockdown due to household activities. Nonetheless, decentralised treatment for greywater is needed to reduce the pollution load in the sewage treatment plant. The transport of greywater produced from the residential buildings to sewage treatment usually takes a certain distance. There is a possibility of greywater runoff due to sewerage network leakage or disruption because of poor maintenance. Greywater is an alternative source for water reuse mechanism; however, organic matter in the greywater may prevent phosphorous adsorption. Therefore, before discharging into the stream, greywater runoff should be treated because it will pollute fresh water and affect aquatic life in the stream. This scenario was resulting higher probability of decreases quantities of clean water. To mitigate water scarcity and accomplish water sustainability in urban areas, the greywater runoff must be treated by a decentralised treatment system such as filtration and on-site greywater reuse treatment system.

Greywater is the wastewater produced from houses such as bathtubs, shower, hand basins, kitchen sinks, dish washer, and laundry machines. Greywater is a fraction of household wastewater with lower pollutant concentration (Boano et al. 2020). Greywater from urban runoff consists 
of body care products, food residue, oil, body fat, hair, bleaches and develop pollutants distinguished from organic carbon, total solid, total suspended solid, and nutrients (Noutsopoulos et al. 2018). Oktor and Çelik (2019) reported the greywater contribute over $50 \%$ of residential wastewater.

The urban runoff from greywater is usually discharged into the stream network and carries amount of dissolved nutrients and leads to low dissolved oxygen. Greywater runoff contamination is one of the issues in growing cities in many urban areas with conventional sewage treatment systems (Liang et al. 2019). Lockdown due to the spread of COVID-19 takes place in every country where people stay at home. As a result, stay at home policy has made the amount of greywater produced increase.

Greywater has the potential to pose degradation to the environment. During the lockdown, the main concern of the increased contaminants is the urban runoff from laundry greywater. The presence of metals and micropollutants poses a possible threat to stream systems and also to public health (Boano et al. 2020). Turner et al. (2019) found that triclosan is an antimicrobial agent and it is commonly used in personal care items, this agent is extremely toxic to algae and the existence of this agent in untreated greywater runoff can impair the reproduction and growth of some aquatic species. Moreover, parabens are esters of the p-hydroxybenzoic acid that have been extensively used as preservatives and antimicrobial agents in cosmetics and personal care products. Therefore, it is frequently detected in air, soil, water resources and human serum (Dionisio et al. 2018).

Production and consumption of greywater toward greywater footprint (GWF) reached 2,630.9 $\mathrm{km}^{3}$ recorded globally in 2019 by 40 countries within three categories which is Brazil, Russia, India and China (BRIC), Organization for Economic Cooperation and Development (OECD) and European Union (EU) countries. The amount of greywater footprint production by BRIC, OECD, and EU countries were produced by $807.5 \mathrm{~km}^{3}, 102.8 \mathrm{~km}^{3}$ and $361.6 \mathrm{~km}^{3}$, respectively. It is found that half of greywater footprint production mainly generated from domestic sources before COVID-19 and China has been identified in BRIC countries as the largest greywater footprint production by a total of $536.6 \mathrm{~km}^{3}$ (Zhao et al. 2019). However, during the pandemic of COVID-19, the greywater footprint production in China has increased rapidly by $1,574 \mathrm{~km}^{3}$ in the year 2020. The greywater footprint production can be classified into three categories including local consumption, other provinces consumption, and foreign consumption. Hereby, $58 \%$ of greywater footprint production was produced from local consumption (Li et al. 2021). It can be concluded, a total of $1,037.4 \mathrm{~km}^{3}$ of greywater footprint production increased during the COVID-19 pandemic from 2019 to 2020 in China itself.

\section{Zoonotic diseases in fish and marine mammals}

World Health Organization define zoonoses as diseases or infections that naturally transmitted from animals to human. Zoonotic diseases could be transmitted in virus, bacteria, or parasite forms. A virus is the smallest infectious microorganism but bacteria usually larger than a virus. Parasite is considered an organism as it could be in a cell size or in multiple cells such as worms. Viruses acquire energy from host cells while parasite require complex diet which consist of sugars, proteins and fats. Parasites have many features that is similar to human cells and able to replicate inside or outside of host. Those three zoonotic agents caused infectious diseases transmitted from animals and are capable of infecting humans (Atawodi et al. 2013).

Coronaviruses such as COVID-19 are common pathogens of the respiratory system and gastrointestinal tract in domestic and wildlife. Concern has been raised either this virus will contaminate the fish as the main protein source of maritime countries. Hemida and Abduallah (2020) listed five genera of coronavirus that usually infect only birds and mammals. None of the listed genera belong to the family Coronaviridae. Coronaviruses are also targeting the respiratory tract with pathology of the lung, which is absent in fish, hence this virus are not susceptible to fish. This virus cannot host on living fish due to the difference between evolves of their innate defence in mammals and fish (Bondad-Reantaso et al. 2020).

However, the probability of coronavirus transmission from surface contamination due to handling by infected people should not be neglected. The potential of transmission might vary depending on the survival period of the virus, but no data available regarding the survival on the surface of seafood so far (van Doremalen et al. 2020). Infection of coronavirus to fish might seem impossible, but this virus has been detected in Pacific harbour seals, beluga whales, and Indo-Pacific bottlenose dolphins (Nollens et al. 2010; Woo et al. 2014). The virus was also detected in the seal that genetically close to feline, canine, and ferrets virus, suggesting the transfer of the virus from terrestrial animal to marine mammals. Differ from the influenza virus, investigations on the impact of coronavirus on marine life are yet to be published. The previous reports on this virus in marine mammals justify the potential transmission, transfer and transportation of this virus from terrestrial animal to marine mammals that require further investigation. 


\section{CONCLUSION}

The coronavirus disease 2019 or COVID-19 pandemic has spread very rapidly throughout the world since end of December 2019 to the present day. Since the lockdown has been implemented in almost all countries, there has been a loss to the world's economy. Although this pandemic poses a serious threat to human health, environmental pollutions from sea to space is declining and nature is recovering to almost the ambient condition. The positive environmental impact we have seen today may be temporary before the nation begins its daily economic and social activities as usual. We should learn from this incident how to reduce the negative impact on our environment on a long-term basis for sustainability and future generation. Since this outbreak has disrupted lives and killed many people, we need to understand the importance of the link between human well-being and the environment, particularly in the aquatic environment.

\section{ACKNOWLEDGEMENTS}

The authors wish to acknowledge their gratitude to the anonymous reviewers who gave free time and effort, constructive recommendations that enhanced the value of this paper.

\section{REFERENCES}

Abdullah, S., Mansor, A.A., Napi, N.N.L.M., Mansor, W.N.W., Ahmed, A.N., Ismail, M. \& Ramly, Z.T.A. 2020. Air quality status during 2020 Malaysia Movement Control Order (MCO) due to 2019 novel coronavirus (2019-nCoV) pandemic. Science of The Total Environment 729: 139022.

Adhikari, S., Meng, S., Wu, Y.J., Mao, Y.P., Ye, R.X., Wang, Q.Z., Sun, C., Sylvia, S., Rozelle, S., Raat, H. \& Zhou, H. 2020. Epidemiology, causes, clinical manifestation and diagnosis, prevention and control of coronavirus disease (COVID-19) during the early outbreak period: A scoping review. Infectious Diseases of Poverty 9: 29. https://doi. org/10.1186/s40249-020-00646-X.

Ahmad, T., Khan, M., Haroon, Musa, T.H., Nasir, S., Hui, J., Bonilla-Aldana, D.K. \& Ridriguez-Morales, A.J. 2020. COVID-19: Zoonotic aspects. Travel Medicine and Infectious Disease 36: 101607.

Akdogan, Z. \& Guven, B. 2019. Microplastics in the environment: A critical review of current understanding and identification of future research needs. Environmental Pollution 254: 13011.

Alcaca, A.C. \& Gomes, E.D. 1979. Recolonization and growth of hermatypic corals in dynamite-blasted coral reefs in the Central Visayas, Philippines. Proceedings of the International Symposium on Marine Biogeography and Evolution in the Southern Hemisphere, New Zealand 137(2): 645-661.
Álvarez-Ruiz, R. \& Picó, Y. 2020. Analysis of emerging and related pollutants in aquatic biota. Trends Environ. Analytical Chemistry 25: e00082.

Andrady, A. 2017. The plastic in microplastics: A review. Marine Pollution Bulletin 119: 12-22.

Aspillaga, E., Bartumeus, F., Linares, C., Starr, R.M., LópezSanz, À., Díaz, D., Zabala, M. \& Hereu, B. 2016. Ordinary and extraordinary movement behaviour of small resident fish within a Mediterranean Marine Protected Area. PLoS ONE 11(7): e0159813.

Atawodi, J.C., Dzikwi, A.A., Odoba, N.B. \& Dagai, D.D. 2013. Animals as reservoir of some human diseases. Electronic Journal of Biology 9(2): 24-28.

Baron, S.A., Devaux, D., Colson, P., Raoult, D. \& Rolain, J.M. 2020. Teicoplanin: An alternative drug for the treatment of coronavirus COVID-19. International Journal of Antimicrobial Agents 55(4): 105944.

Batista, N.J.C., Cavalcante, A.A.C.M., Oliveira, M.G., Medeiros, E.C.N., Machado, J.L., Evangelista, S.R., Dias, J.F., Dos Santos, C.E.I., Duarte, A., da Silva, F.R. \& da Silva, J. 2016. Genotoxic and mutagenic evaluation of water samples from a river under the influence of different anthropogenic activities. Chemosphere 164: 134-141.

Bennett, N.J., Finkbeiner, E.M., Ban, N.C., Belhabib, D., Jupiter, S.D., Kittinger, J.N., Mangubhai, S., Schiltens, J. \& Christie, P. 2020. The COVID-19 pandemic, smallscale fisheries and coastal fishing communities. Coastal Management 48(4): 336-347.

Bilkovic, D.M., Mitchell, M.M., Davis, J., Herman, J., Andrews, E., King, A., Mason, P., Tahvildari, N., Davis, J. \& Lixon, R.L. 2019. Defining boat wake impacts on shoreline stability toward management and policy solutions. Ocean and Coastal Management 182: 104945.

Boano, F., Caruso, A., Costamagna, E., Ridolfi, L., Fiore, S., Demichelis, F., Galvao, A., Pisoeiro, J., Rizzo, A. \& Masi, F. 2020. A review of nature-based solutions for greywater treatment: Applications, hydraulic design, and environmental benefits. Science of The Total Environment 711: 134731.

Bondad-Reantaso, M.G., Mackinnon, B., Bin, H., Jie, H., TangNelson, K., Surachetpong, W., Alday-Sanz, V., Salman, M., Brun, E., Karunasagar, I., Hanson, L., Sumption, K., Barange, M., Lovatelli, A., Sunarto, A., Fejzic, N., Subasinghe, R., Mathiesen, A.M. \& Shariff, M. 2020. SARS-CoV-2 (The cause of COVID-19 in humans) is not known to infect aquatic food animals nor contaminate their products. Asian Fisheries Science 33(1): 74-78.

Braga, F., Scarpa, G.M., Brando, V.E., Manfe, G. \& Zaggia, L. 2020. COVID-19 lockdown measures reveal human impact on water transparency in the Venice Lagoon. Science of The Total Environment 736: 139612.

Brodersen, K.E., Koren, K., Revsbech, N.P. \& Kuhl, M. 2020. Strong leaf surface basification and $\mathrm{CO}_{2}$ limitation of seagrass induced by epiphytic biofilm microenvironments. Plant, Cell and Environment 43: 174-187.

Brunton, J. 2020. Nature is taking back Venice: Wildlife returns to tourist-free city. The Guardian 20 Mar. 2020. hhps://www. 
theguardian.com/environment/2020/mar/20/nature-is-takingback-venice-wildlife-returns-to-tourist-free-city.

Burgin, S. \& Hardiman, N. 2011. The direct physical, chemical and biotic impacts on Australian coastal waters due to recreational boating. Biodiversity and Conservation 20: 683-701.

Chakraborty, C., Sharma, A.R., Bhattacharya, M., Sharma, G. \& Lee, S.S. 2020. The 2019 novel coronavirus disease (COVID-19) pandemic: A zoonotic prospective. Asian Pacific Journal of Tropical Medicine 13: 242-246.

Chen, K., Wang, M., Huang, C., Kinney, P.L. \& Anastas, P.T. 2020. Air pollution reduction and mortality benefit during the COVID-19 outbreak in China. The Lancet Planetary Health 4(6): 210-222.

Connell, S.D., Doubleday, Z.A., Hamlyn, S.B., Foster, N.R., Harley, C.D.G., Helmuth, B., Kelaher, B.P., Nagelkerken, I., Sara, G. \& Russell, B.D. 2017. How ocean acidification can benefit calcifiers. Current Biology 27: 95-96.

Courtene-Jones, W., Quinn, B., Murphy, S.F. \& Narayanaswamy, B.E. 2017. Optimisation of enzymatic digestion and validation of specimen preservation methods for the analysis of ingested microplastics. Analytical Methods 9: $1437-1445$

Deshwal, V.K. 2020. COVID 19: A comparative study of Asian, European, American continent. International Journal of Scientific Research and Engineering Development 3: 436440.

DeVries, T., Holzer, M. \& Primeau, F. 2017. Recent increase in oceanic carbon uptake driven by weaker upper-ocean overturning. Nature 542: 215-218.

Dionisio, D., Motheo, A.J., Saez, C. \& Rodrigo, M.A. 2018. Effect of the electrolyte on the electrolysis and photoelectrolysis of synthetic methyl paraben polluted wastewater. Separation and Purification Technology 208: 201-207.

Doney, S.C., Fabry, V.J., Feely, R.A. \& Kleypas, J.A. 2009. Ocean acidification: The other $\mathrm{CO}_{2}$ problem. Annual Review of Marine Science 1: 169-192.

Dutheil, F., Baker, J.S. \& Navel, V. 2020. COVID-19 as a factor influencing air pollution? Environmental Pollution 263: 114466.

Edinger, E.N., Jompa, J., Limmon, G.V., Widjatmoko, W. \& Risk, M.J. 1998. Reef degradation and coral biodiversity in Indonesia: Effects of land-based pollution, destructive fishing practices and changes over time. Marine Pollution Bulletin 36(8): 617-630

Edward, J.K.P., Jayanthi, M., Malleshappa, H., Jeyasanta, I., Laju, R.L., Patterson, J., Diraviya Raj, K., Mathews, G., Marimuthu, A.S. \& Grimsditch, G. 2021. COVID-19 lockdown improved the health of coastal environment and enhanced the population of reef-fish. Marine Pollution Bulletin 165: 112124

Eerkes-Medrano, D., Thompson, R.C. \& Aldrigde, D.C. 2015. Microplastics in freshwater systems: A review of the emerging threats, identification of knowledge gaps and prioritisation of research needs. Water Research 75: 63-82.

Eriksen, M., Lebreton, L.C.M., Carson, H.S., Rhiel, M., Moore, C.J. \& Borerro, J.C. 2014. Plastic pollution in the world's oceans: More than 5 trillion plastic pieces weighing over 250,000 tons afloat at sea. PLoS ONE 9(12): e111913.

Fanin, A., Calegari, J., Beverina, A. \& Tiraboschi, S. 2020. Hydroxychloroquine and azithromycin as a treatment of COVID-19. Internal and Emergency Medicine 15: 841-843.

Fattorini, D. \& Regoli, F. 2020. Role of the chronic air pollution levels in the Covid-19 outbreak risk in Italy. Environmental Pollution 264: 114732

Fernandes, A.M., Conceição, F.T. \& Mortatt, J. 2020 Hydrochemistry applied to assess the chemical weathering and soil removal rates in the Sorocaba River basin, São Paulo State. Brazilian Journal of Geology 50: e20190030.

Freitas, E.D., Ibarra-Espinosa, S.A. \& Gavidia-Calderón, M.E. 2020. Mobility restrictions and air quality under COVID-19 pandemic in São Paulo, Brazil. Preprints 2020: 040515.

Gagliano, M., McCormick, M.I., Moore, J.A. \& Depczynski, M. 2010. The basics of acidification: Baseline variability of $\mathrm{pH}$ on Australian coral reefs. Marine Biology 157: 18491856.

Goi, C.L. 2020. The river water quality before and during the Movement Control Order (MCO) in Malaysia. Case Studies in Chemical and Environmental Engineering 2: 100027.

Gordon, L.J. 2020. The Covid-19 pandemic stress the need to build resilient production ecosystems. Agriculture and Human Values 37: 645-646.

Hamzelou, J. 2020. World in lockdown. NewScientist 245: 7. https://doi.org/10.1016/S0262-4079(20)30611-4.

Hemida, M.G. \& Abduallah, M.M.B. 2020. The SARS-CoV-2 outbreak from a one health perspective. One Health 10: 100127.

Hughes, T.P., Barnes, M.L., Bellwood, D.R., Cinner, J.E., Cumming, G.S., Jackson, J.B.C., Kleypas, J., van de Leemput, I.A., Lough, J.M., Morrison, T.H., Palumbi, S.R., van Nes, E.H. \& Scheffer, M. 2017. Coral reefs in the Anthropocene. Nature 546: 82-90.

Jiang, J., Li, S., Wang, X., Li, C., Sun, Z., Liu, W., Duan, F. \& $\mathrm{Fu}, \mathrm{X}$. 2021. Study of the relationship between sound signals and behaviors of a sperm whale during the hunting process Applied Acoustics 174: 107745

Jobling, S., Williams, R., Johnson, A., Taylor, A., Gross-Sorokin, M., Nolan, M., Tyler, C.R., van Aerle, R., Santos, E. \& Brighty, G. 2006. Predicted exposures to steroid estrogens in U.K. rivers correlate with widespread sexual disruption in wild fish populations. Environmental Health Perspective 114(1): 32-39.

King, C., Iba, W. \& Clifton, J. 2021. Reimagining resilience: COVID-19 and marine tourism in Indonesia. Current Issues in Tourism https://doi.org/10.1080/13683500.2021.1873920.

Kitidis, V., Brown, I. \& Hardman-Mountford, N. 2017. Surface ocean carbon dioxide during the Atlantic Meridional transect (1995-2013): Evidence of ocean acidification. Progress in Oceanography 158: 65-75.

Korten, T. 2020. With boats stuck in harbor because of COVID-19, will fish bounce back? https://www. smithsonianmag.com/science-nature/fish-stopcovid-19-180974623. 
Lau, H., Khosrawipour, V., Kobach, P., Mikolajczyk, A., Schubert, J., Bania, J. \& Khosrawipour, T. 2020. The positive impact of lockdown in Wuhan on containing the COVID-19 outbreak in China. Journal of Travel Medicine 27: 37.

Lee, J.N. \& Mohamed, C.A.R. 2011. Accumulation of settling particles in some coral reef areas of Peninsular Malaysia. Sains Malaysiana 40(6): 549-554.

Li, H., Liang, S., Liang, Y., Li, K., Qi, J., Yang, X., Feng, C., Cai, Y. \& Yang, Z. 2021. Multi-pollutant based grey water footprint of Chinese regions. Resources, Conservation and Recycling 164: 105202.

Liang, X., Cui, S., Li, H., Abdelhady, A., Wang, H. \& Zhou, H. 2019. Removal effect on stormwater runoff pollution of porous concrete treated with nanometer titanium dioxide. Transportation Research Part D: Transport and Environment 73: 34-45.

Loflen, C.L., Buck, T., Bonnema, A. \& Heim, W.A. 2018. Pollutant bioaccumulation in the California spiny lobster (Panulirus interruptus) in San Diego Bay, California, and potential human health implications. Marine Pollution Bulletin 128: 585-592.

Lokhandwala, S. \& Gautam, P. 2020. Indirect impact of COVID-19 on environment: A brief study in Indian context. Environmental Research 188: 109807.

Lough, J.M., Anderson, K.D. \& Hughes, T.P. 2018. Increasing thermal stress for tropical coral reefs: 1871-2017. Scientific Report 6: 6079.

Lu, H., Stratton, C.W. \& Tang, Y. 2020. Outbreak of pneumonia of unknown etiology in Wuhan China: The mystery and the miracle. Journal of Medical Virology 92: 401-402.

Mazzoni, R., Pinto, M.P., Ingesias-Rios, R. \& Costa, R. 2018. Fish movement in an Atlantic Forest stream. Neotropical Ichthyology 16: e170065.

Mitra, A., Chaudhuri, T.R., Mitra, A., Pramanick, P. \& Zaman, S. 2020. Impact of COVID-19 related shutdown on atmospheric carbon dioxide level in the city of Kolkata. Parana Journal of Science and Education 6(3): 84-92.

Nicola, M., Alsafi, Z., Sohrabi, C., Kerwan, A., Al-Jabir, A., Losifidis, C., Agha, M. \& Agha, R. 2020. The socio-economic implications of the coronavirus pandemic (COVID-19): A review. International Journal of Surgery 78: 185-193.

Nollens, H.H., Wellehan, J.F.X., Archer, L., Lowenstine, L.J. \& Gulland, F.M.D. 2010. Detection of a respiratory coronavirus from tissues archived during a pneumonia epizootic in free-ranging Pacific harbor seals Phoca vitulina richardsii. Diseases of Aquatic Organisms 90(2): 113-120.

Noutsopoulos, C., Andreadakis, A., Kouris, N., Charchousi, D., Mendrinou, P. \& Galani, A. 2017. Greywater characterization and loadings - Physicochemical treatment to promote onsite reuse. Journal of Environmental Management 216: 337 346.

Oktor, K. \& Dicle, C. 2019. Treatment of wash basin and bathroom greywater with Chlorella variabilis and reusability. Journal of Water Process Engineering 31: 100857.
Omar, T.F.T., Aris, A.Z., Yusoff, F.M. \& Mustafa, S. 2019a. Risk assessment of pharmaceutically active compounds (PhACs) in the Klang River estuary, Malaysia. Environmental Geochemistry and Health 41(1): 211-223.

Omar, T.F.T., Aris, A.Z., Yusoff, F.M. \& Mustafa, S. 2019b. Occurrence and level of emerging organic contaminant in fish and mollusk from Klang River estuary, Malaysia and assessment on human health risk. Environmental Pollution 248: 763-773.

Omar, T.F.T., Aris, A.Z., Yusoff, F.M. \& Mustafa, S. 2018. Occurrence, distribution, and sources of emerging organic contaminants in tropical coastal sediments of anthropogenically impacted Klang River estuary, Malaysia. Marine Pollution Bulletin 131: 284-293.

Ong, M.C. \& Gan, S.L. 2017. Assessment of metallic trace elements in the muscles and fins of four landed elasmobranchs from Kuala Terengganu Waters, Malaysia. Marine Pollution Bulletin 124: 1001-1005.

Peng, C., Zhao, X. \& Liu, G. 2015. Noise in the sea and its impacts on marine organisms. International Journal of Environmental Research and Public Health 12: 12304-12323.

Praveena, S.M. \& Aris, A.Z. 2021. The impacts of COVID-19 on the environmental sustainability: A perspective from the Southeast Asian region. Environmental Science and Pollution Research 2021. https://doi.org/10.1007/s11356-020-11774-0.

Praveena, S.M., Shaifuddin, S.N.M., Sukiman, S., Nasir, F.A.M., Hanafi, Z. \& Kamarudin, N. 2018. Pharmaceuticals residues in selected tropical surface water bodies from Selangor (Malaysia): Occurrence and potential risk assessments. Science of The Total Environment 642: 230-240.

Praveena, S.M., Siraj, S.S. \& Aris, A.Z. 2012. Coral reefs studies and threats in Malaysia: A mini review. Reviews in Environmental Science and Biotechnology 11: 27-39.

Quilliam, R.S., Weidmann, M., Moresco, V., Purshouse, H., O'Hara, Z. \& Oliver, D.M. 2020. COVID-19: The environmental implications of shedding SARS-CoV-2 in human faeces. Environment International 140: 105790.

Rako-Gospić, N. \& Picciulin, M. 2019. Underwater noise: Sources and effects on marine life. World Seas: An Environmental Evaluation (Second Edition) 2019: 367-389.

Raven, J.A. 2005. Ocean Acidification due to Increasing Atmospheric Carbon Dioxide. London: The Royal Society. p. 59.

Saadat, S., Rawtani, D. \& Hussain, C.M. 2020. Environmental perspective of COVID-19. Science of The Total Environment 728: 138870 .

Sagerman, J., Hansen, J.P. \& Wikström, S.A. 2020. Effects of boat traffic and mooring infrastructure on aquatic vegetation: A systematic review and meta-analysis. Ambio 49: 517-530.

Salleh, S.M., Sah, S.A.M. \& Chodhury, A.J.K. 2018. Assessing nesting status of green turtles, Chelonia mydas in Perak, Malaysia. Tropical Life Sciences Research 29: 155-171.

Seraphim, M.J., Sloman, K.A., Alexander, M.E., Janetski, N., Jompa, J., Ambo-Rappe, R., Snellgrove, D., Mars, F. \& 
Harborne, A.R. 2020. Interactions between coral restoration and fish assemblages: Implications for reef management. Journal of Fish Biology 97(3): 633-655.

Shereen, M.A., Khan, S., Kazmi, A., Bashir, N. \& Siddique, R. 2020. COVID-19 infection: Origin, transmission, and characteristics of human coronaviruses. Journal of Advanced Research 24: 91-98.

Sim, W.J., Kim, H.Y., Choi, S.D., Kwon, J.H. \& Oh, J.E. 2013. Evaluation of pharmaceuticals and personal care products with emphasis on anthelmintics in human sanitary waste, sewage, hospital wastewater, livestock wastewater and receiving water. Journal of Hazardous Materials 248: 219227.

Sohrabi, C., Alsafi, Z., O’Neill, N., Khan, M., Kerwan, A., Al-Jabir, A., Iosifidis, C. \& Agha, R. 2020. World Health Organization declares global emergency: A review of the 2019 novel coronavirus (COVID-19). International Journal of Surgery 76: 71-76.

Steneck, R.S., Arnold, S.N., Boenish, R., de Leon, R., Mumby, P.J., Rasher, D.B. \& Wilson, M. W. 2019. Managing recovery resilience in coral reefs against climate-induced bleaching and hurricanes: A 15 years case study from Bonaire, Dutch Caribbean. Frontier in Marine Science 6: 265.

Stocker, M. 2002. Ocean bio-acoustics and noise pollution: Fish, mollusks and other sea animals' use of sound, and the impact of anthropogenic noise on the marine acoustic environment. Soundscape: The Journal of the Acoustical Society of America 3-4(1): 16-29.

Suhaimi, N.F., Jalaludin, J. \& Latif, M.T. 2020. Demystifying a possible relationship between COVID-19, air quality and meteorological factors: Evidence from Kuala Lumpur, Malaysia. Aerosol and Air Quality Research 20: 1520-1529.

The Guardian. 2020. 'More Masks than Jellyfish': Coronavirus Waste Ends up in Ocean. https://www.theguardian.com/ environment/2020/jun/08/more-masks-than-jellyfishcoronavirus-waste-ends-up-in-ocean

The Star. 25 April 2020. Thanks to MCO, Sungai Melaka is Green and Clean. https://www.thestar.com.my/news/ nation/2020/04/25/thanks-to-mco-sungai-melaka-is-greenand-clean.

Thomson, D.J.M. \& Barclay, D.R. 2020. Real-time observations of the impact of COVID-19 on underwater noise. Journal of the Acoustical Society of America 147: 3390.

Tobías, A., Carnerero, C., Reche, C., Massagué, J., Via, M., Minguillón, M.C., Alastuey, A. \& Querol, X. 2020. Changes in air quality during the lockdown in Barcelona (Spain) one month into the SARS-CoV-2 epidemic. Science of The Total Environment 726: 138540.

Turner, R.D.R., Warne, M.S.J., Dawes, L.A., Thompson, K. \& Will, G.D. 2019. Greywater irrigation as a source of organic micro-pollutants to shallow groundwater and nearby surface water. Science of The Total Environment 669: 570-578

van Doremalen, N., Morris, D.H., Holbrook, M.G., Gamble, A., Williamson, B.N., Tamin, A., Lloyd-Smith, J.O. \& de Wit, E. 2020. Aerosol and surface stability of SARS-CoV-2 as compared with SARS-CoV-1. The New England Journal of Medicine 382(16): 1564-1567.

Van Lancker, W. \& Parolin, Z. 2020. COVID-19, school closures, and child poverty: A social crisis in the making. The Lancet 5: 243-244.

Wang, Q. \& Su, M. 2020. A preliminary assessment of the impact of COVID-19 on environment: A case study of China Science of The Total Environment 728: 138915.

Wenham, C., Smith, J. \& Morgan, R. 2020. COVID-19: The gendered impacts of the outbreak. The Lancet 395: 846-848.

WHO. 2020. Q\&A on coronaviruses (COVID-19). https://www. who.int/emergencies/diseases/novel-coronavirus-2019/ question-and-answers-hub/q-a-detail/q-a-coronaviruses.

Williamson, P., Turley, C.M. \& Ostle, C. 2017. Ocean acidification. MCCIP Science Review 2017: 1-14.

Woo, P.C.Y., Lau, S.K.P., Lam, C.S.F. \& Tsang, A.K.L. 2014 Discovery of a novel bottlenose dolphin coronavirus reveals a distinct species of marine mammal coronavirus in Gammacoronavirus. Journal of Virology 88(2): 1318-1331.

World Economic Forum. 2020. How Face Masks, Gloves and Other Coronavirus Waste is Polluting Our Ocean. https:// www.weforum.org/agenda/2020/06/ppe-masks-glovescoronavirus-ocean-pollution/.

Zanin, G.M., Gentile, E., Parisi, A. \& Spasiano, D. 2020. A preliminary evaluation of the public risk perception related to the COVID-19 health emergency in Italy. International Journal of Environmental Research and Public Health 17: 3024.

Zhao, X., Liao, X., Chen, B., Tillotson, M.R., Guo, W. \& Li, Y. 2019. Accounting global grey water footprint from both consumption and production perspectives. Journal of Cleaner Production 225: 963-971.

Zhu, Y., Xie, J., Huang, F. \& Cao, L. 2020a. Association between short-term exposure to air pollution and COVID-19 infection: Evidence from China. Science of The Total Environment 727: 138704

Zhu, L., Ciais, P., Zhu, Deng,, Ruixue, L., Davis, S.J., Sha, F., Zheng, B., Cui, D., Dou, X., Zhu, B., Guo, R., Ke, P., Sun, T., Lu, C., He, P., Wang, Y., Yue, X., Wang, Y., Lei, Y., Zhou, H., Cai, Z., Wu, Y., Guo, R., Han, T., Xue, J., Boucher, O., Boucher, E., Chevallier, F., Tanaka, K., Wei, Y., Zhong, H., Kang, C., Zhang, N., Chen, B., Xi, F., Liu, M., Bréon, F-M., Lu, Y., Zhang, Q., Guan, D., Gong, P., Kammen, D.M., He, K. \& Schellnhuber, H.J. 2020b. Near-real-time monitoring of global $\mathrm{CO} 2$ emissions reveals the effects of the COVID-19 pandemic. Nature Communication 11: 5172.

Ong Meng Chuan*, Adiana Ghazali, Roswati Md Amin, Kesaven Bhubalan, Lee Jen Nie, Tuan Mohamad Fauzan Tuan Omar, Idham Khalil, Suvik Assaw, Yong Jaw Chuen, Nurulnadia Mohd Yusoff \& Izan Jaafar

Faculty of Science and Marine Environment

Universiti Malaysia Terengganu

21030 Kuala Nerus, Terengganu Darul Iman Malaysia 
Ong Meng Chuan*, Adiana Ghazali, Roswati Md Amin, Kesaven Bhubalan, Lee Jen Nie, Tuan Mohamad Fauzan Tuan Omar, Idham Khalil, Suvik Assaw, Yong Jaw Chuen, Nurulnadia Mohd Yusoff, Izan Jaafar \& Wan Nurul Nadiah Wan Rasdi Ocean Pollution and Ecotoxicology (OPEC) Research Group Universiti Malaysia Terengganu 21030 Kuala Nerus, Terengganu Darul Iman Malaysia

Ong Meng Chuan*

Institute of Oceanography and Environment Universiti Malaysia Terengganu

21030 Kuala Nerus, Terengganu Darul Iman Malaysia

Wan Nurul Nadiah Wan Rasdi

Faculty of Fisheries and Food Sciences

Universiti Malaysia Terengganu

21030 Kuala Nerus, Terengganu Darul Iman

Malaysia

Nurzafirah Mazlan \& Miftahul Jannah Muhammad Husin Faculty of Health and Life Sciences

Management and Science University

Seksyen 13, University Drive

40100 Shah Alam, Selangor Darul Ehsan

Malaysia
Radin Maya Saphira Radin Mohamed

Micropollutant Research Centre (MPRC)

Faculty of Civil and Environmental Engineering

Universiti Tun Hussein Onn

86400 Parit Raja, Batu Pahat, Johor Darul Takzim

Malaysia

Zurahanim Fasha Anual

Environmental Health Research Centre

Institute for Medical Research

Jalan Pahang,

50588 Kuala Lumpur, Federal Territory

Malaysia

Chen Mengli

Tropical Marine Science Institute National University of Singapore

18 Kent Ridge Rd, Singapore 119227

Singapore

Marfiah Ab Wahid

Micropollutant \& Pathogen in Water Research Group

Universiti Teknologi MARA

40450 Shah Alam, Selangor Darul Ehsan

Malaysia

*Corresponding author; email: ong@umt.edu.my

Received: 25 January 2021

Accepted: 15 March 2021 